\title{
Comparison of aflatoxins contamination levels in betel nuts (Areca catechu L.) imported from Asian countries
}

\author{
Muhammad Asif Asghar ${ }^{1}$, Aftab Ahmed ${ }^{1}$ and Muhammad Arif Asghar ${ }^{2^{*}}$ (1)
}

\begin{abstract}
Background: Aspergillus and their linked metabolites such as aflatoxins (AFs) are one of the extremely significant contaminants affecting food production around the world. The contamination of AFs has been identified in various food commodities, which have been recognized as carcinogenic, mutagenic, teratogenic and immunosuppressive. The present study was undertaken to assess the AFs contamination in betel nuts (Areca catechu L.) being imported to Pakistan from South Asian countries during 2018-2019.

Methods: A total of 143 betel nuts consignments (India $=80$, Indonesia $=39$ and Sri Lanka $=24$ ) were obtained and analyzed for the AF contamination using immunoaffinity column (IAC) clean-up procedure subsequent by liquid chromatography with fluorescence detection. Results: In Indian-origin betel nuts, about $96.3 \%$ samples were contaminated with AFs, ranging from $1.18-331.57 \mu \mathrm{g} / \mathrm{kg}$ with mean contamination of $76.11 \pm 1.12 \mu \mathrm{g} / \mathrm{kg}$; whereas, in Indonesian and Sri Lankan shipments, $100 \%$ samples of betel nuts were found infected with AFs, ranging between $1.88-378.94$ and $4.74-106.58 \mu \mathrm{g} / \mathrm{kg}$ with an average level of $123.76 \pm 1.25$ and $47.95 \pm 0.98 \mu \mathrm{g} / \mathrm{kg}$, respectively.

Conclusions: In conclusion, the AFs levels present an acute toxicity to human health and also hazard factors for the economy since contaminated foodstuffs do not fulfill the requirements of export/import. Therefore, instant actions should be engaged and re-evaluate agricultural procedures and regular monitoring of AFs level in food stuffs to minimize the chances of various diseases such as oral pre-cancerous oral wounds, submucous fibrosis and squamous cell carcinoma (cancer).
\end{abstract}

Keywords: Betel nuts, Aflatoxins, HPLC-FLD, Pakistan, South Asian countries

\section{Background}

Betel nut (Areca catechu L.) is the fruit of the oriental palm and cultivated in several tropical Southeast and South Asian countries. The betel nut commonly used in the form supari, pan masala and gutka in several societies of Pakistan. In addition, the few pieces of nut are chewing, which are enfolded in a betel leaves with calcium

\footnotetext{
*Correspondence: m.arifasgher@hotmail.com

${ }^{2}$ Department of Pharmaceutics, Faculty of Pharmacy, Jinnah Sindh

Medical University, Rafiqui H.J Shaheed Road, Karachi 75510, Sindh, Pakistan

Full list of author information is available at the end of the article
}

hydroxide, catechu (kattha), saffron, cardamom, turmeric, clove or sweeteners [1].

The long-term habit of betel nut has been connected with various diseases such as oral pre-cancerous oral wounds (mouth injuries), submucous fibrosis and squamous cell carcinoma (cancer) [2]. The constant chewing of betel nuts is responsible for teeth/gums, mouth, lips deterioration or red stained, development of oral cavities, burning and dryness of mouth and stones in kidney [3]. Prolonged or acute effects of betel nuts chewing includes deteriorating of asthma, diabetes, low blood circulation, tachycardia and irregular heartbeat, resulting in the risk of mouth, esophagus, pharynx, 
stomach prostate, cervix and liver carcinomas [4]. Chewing of betel nuts is also able to produce nausea, diarrhea, vomiting, chest pain and cramps. Moreover, chewing of betel nuts has been documented as a carcinogen for human being by International Agency for Research on Cancer (IARC) [5].

Betel nut is susceptible to the formation of toxigenic mold growth during various stages of harvesting, storage and transportation. A contaminated pod will have a dark patch appearance inside the nut if it has been infested by fungi. The fungal strains Aspergillus are able to grow on betel nuts under suitable conditions and produced carcinogenic metabolites such as aflatoxins (AFs). In addition, betel nuts are frequently cultivated in countries where environmental conditions are considered as tropical, humid, high temperatures and heavy rainfall [6]. These environments are promising for the growth of aflatoxigenic fungi and finally AFs production. The carcinogenic, hepatogenic, mutagenic, neoplastic and immunosuppressing effects of AFs have described in previous study [7]. The extremely significant group of AFs is aflatoxin B1, B2, G1 and G2; whereas, aflatoxin B1 is the utmost abundant and poisonous member of family and has been categorized by the World Health Organization as "group A" carcinogen since its confirmed association to the pathogenesis of hepatocellular carcinoma and used as marker of hepatitis $\mathrm{C}$ virus (HCV) infection in asymptomatic patients [8]. Acute diseases such as cirrhosis, liver necrosis, encephalopathy and amplified vulnerability to hepatitis B can be associated with the ingested quantity and intake frequency of AFs and the age of individual consumers [9].

In generally, tropical and sub-tropical environments such as moisture, high temperature, unseasonal and heavy rains and flash floods are prime factors that propagate the fungal growth and eventually the AFs production [10]. In South Asian countries, the climatic environments are usually very warm and moist and offer an excellent condition for fungal proliferation and AFs production. Nearness to sea also plays an important part in this account. Due to carcinogenicity associated with betel nuts, none of the countries in the world has established maximum tolerated limit (MTL) for AFs in betel nut. However, only India has prescribed MTL for AFs in betel nut at $15 \mu \mathrm{g} / \mathrm{mL}$ [11].

Various reports are available on the presence of AFs contamination in several food commodities [12]. However, information with reference to AFs in betel nuts is still very inadequate. Hence, this study was carried out to evaluate the AFs contamination level in betel nuts being exported from various South Asian countries to Pakistan and to make public attentive to the epidemiological effects of contaminated betel nuts.

\section{Materials and methods}

\section{Reagents and apparatus}

The high-performance liquid chromatography (HPLC) standards of AFBl, AFB2, AFGl and AFG2 in acetonitrile $(\mathrm{ACN})$ were received from Biopure (Austria). The analytical grade methanol $(\mathrm{MeOH})$ and $\mathrm{ACN}$ were acquired from Merck (Germany). Potassium bromide and nitric acid were purchased from Sigma-Aldrich (USA). Saline tablets of phosphate buffered (PBS) $(\mathrm{pH} 7.4 \pm 0.1)$ were acquired from Oxoid (England). The highly distilled water $(18 \mathrm{M} \Omega \mathrm{cm})$ was arranged by treating de-ionized water (DI-H2O) using a Purelab Ultra Option system (Model \# DV 25; UK). Explosion-proof blender (Model \# 8022) was obtained from Ebarch Corp., (USA). The schematic of a HPLC instrument was acquired from VWRHitachi (Germany) consisting of pump (Model \# L-2250), an auto-sampler (Model \# L-2210) and a detector fluorescence source (Model \# L-2300). A column thermostat was attained from Jones (UK). The separation of AFs was performed using a LiChroCART $100 \AA$ RP- 18 , (5 mm, $250 \times 4.0 \mathrm{~mm} 2$ ) column obtained from Merck (Germany). Immunoaffinity AflaStar ${ }^{\text {TM }}$ columns (IACs) (catalogue no. COIAC1001) were acquired from Romer Labs. (Austria).

\section{Sample collection}

The national bio-security can be well maintained by applying the practical sanitary and phytosanitary guidelines for imports/exports of agricultural commodities. In Pakistan, a well-established system of management and mechanism of import procedure for agricultural commodities is adopted. In this concern, the Department of Customs, Government of Pakistan, strictly monitored and controlled the trading food products transported into Pakistan as per the safety and health aspects. In 20182019, a total of 143 batches of betel nuts (80 from India, 39 from Indonesia, 24 from Sri Lanka) were obtained on arrival at the sea and air port of Karachi city, Pakistan. AFs are produced in concise form in high content and heterogeneously distributed in whole agricultural commodities. Therefore, the representative and homogenized samples of betel nuts were acquired using the official method (no. 977.16.) of Association of Official Agricultural Chemists (AOAC). In brief, about 500-1000 grams sample was mixed entirely for $10 \mathrm{~min}$ and grounded using pestle and mortar then by sample grinder (Sweden). The ground sample was placed on a clean smooth surface, mixed thoroughly and tipped into the center of the working area. The scoop was used to turn the heap of sample from the edge towards the center. The heap was broken down occasionally and reconstructed. The cone was flatted so that its height is less than the width of the quartering board. Then, the heap was divided into 
quarters using the board, first by dividing it into two approximately equal halves and then reducing the halves in similar fashion. Any two diagonally opposite quarters of the sample was removed from the working area. The remaining sample is then thoroughly mixed as described above. The above procedure was repeated as many times as are necessary to reduce the sample to the desired size. Finally, each representative and homogeneous sample was retained in air-tight muddy polyethylene bags at $-20^{\circ} \mathrm{C}$ till further examination.

\section{Quantification of aflatoxins (AFs)}

The quantification of AFs in betel nuts was executed using HPLC and detector of fluorescence source [12]. Briefly, the whole procedure involved sample extraction, AFs purification followed by chromatographic analysis as mentioned below.

\section{Sample preparation (extraction of sample)}

An accurately weighed $25 \mathrm{~g}$ of each pulverized and homogenized sample of betel nuts was distributed in $100 \mathrm{~mL}$ of $\mathrm{DI}-\mathrm{H}_{2} \mathrm{O} / \mathrm{ACN}(40 / 60$; v/v). The suspension form of sample was blended using a blender at $5000 \mathrm{rpm}$ for $2 \mathrm{~min}$. After mixing, the filtration of suspension was performed using filter paper Whatman \# 1 and clear solution was collected in sealed amber vials.

\section{Sample clean-up using immunoaffinity columns}

The AFs separation was performed by immunoaffinity columns (IACs). Briefly, first $2 \mathrm{~mL}$ of sample was diluted with PBS (48 mL; pH 7.4) and passed at a flow rate of 1 to $2 \mathrm{~mL} / \mathrm{min}$ through IACs. The columns were washed with $20 \mathrm{~mL}$ of DI- $\mathrm{H}_{2} \mathrm{O}$ with a flow rate of about $5 \mathrm{~mL} / \mathrm{min}$ and quickly dried by vacuum. Finally, the AFs content were eluted with $\mathrm{MeOH}(1.5 \mathrm{~mL})$ followed washed by DI- $\mathrm{H}_{2} \mathrm{O}$ $(1.5 \mathrm{~mL})$ and collected in separate amber vials for following chromatographic examination.

\section{AFs derivatization and HPLC-FL analysis}

The contamination of AFs was quantified using a fluorescence detector HPLC with post-derivatization of column using Kobra Cell ${ }^{\mathrm{TM}}$. The AFs content was separated using RP-18 column and maintained at $40{ }^{\circ} \mathrm{C}$. An aliquot of $99 \mathrm{~mL}$ of the AFs standards/samples were injected to the HPLC system by auto-sampler. Mobile phase was DI-H2O:ACN:MeOH (55:22.5:22.5; v/v/v) comprising $154 \mathrm{ml} / \mathrm{L}$ of nitric acid and $119 \mathrm{mg} / \mathrm{L}$ of potassium bromide with $1 \mathrm{~mL} / \mathrm{min}$ flow rate. The detector functioned at 333 as excitation and $464 \mathrm{~nm}$ as wavelengths. The whole procedure was operated in an isocratic mode. The total run time for the analysis was about $14 \mathrm{~min}$. Figure $1 \mathrm{a}, \mathrm{b}$ shows the HPLC chromatograms of aflatoxins standard and naturally contaminated samples of betel nuts, respectively.

\section{Validation of HPLC method}

The validation of the utilized HPLC method was performed in agreement with decision 657/2002/EC and regulation no. 401/2006/EC [13, 14]. The accuracy of the analytical method was evaluated by the analysis of each sample in triplicate. In addition, the validation parameters such as accuracy, linearity, limit of quantification (LOQ), limit of detection (LOD), measurement uncertainty, precision, recovery and participation in proficiency program were also evaluated. Tables 1 and 2 show
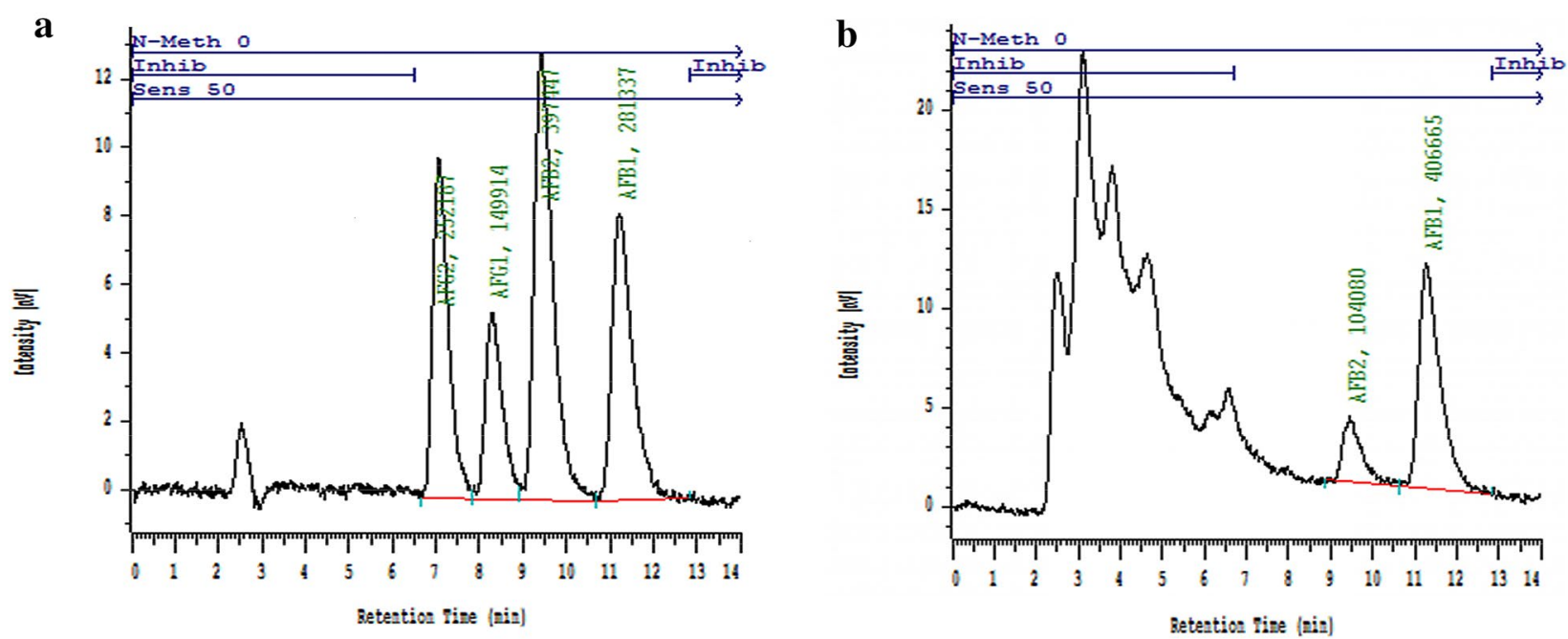

Fig. 1 High-performance liquid chromatography chromatograms of $\mathbf{a}$ aflatoxins standard; and $\mathbf{b}$ naturally contaminated samples of betel nuts 
Table 1 Method performance parameters of HPLC method for the quantification of aflatoxins (AFB1, AFB2, AFG1 and AFG2) in betel nuts

\begin{tabular}{llllllll}
\hline Toxins & $\begin{array}{l}\text { Correlation } \\
\text { coefficient }\left(\boldsymbol{R}^{\mathbf{2}}\right)\end{array}$ & LOD $(\boldsymbol{\mu g} \mathbf{g} \mathbf{k g})$ & LOQ $(\boldsymbol{\mu g} / \mathbf{k g})$ & Recovery range (\%) & $\begin{array}{l}\text { RME (\%) } \\
(\boldsymbol{n}=\mathbf{2 0})\end{array}$ & RSD $(\%)(\boldsymbol{n}=\mathbf{2 0})$ & $\begin{array}{l}\text { Measurement } \\
\mathbf{u n c e r t a i n t y}(\boldsymbol{\mu g} / \\
\mathbf{k g})\end{array}$ \\
\hline $\mathrm{AFB}_{1}$ & 0.9994 & 0.04 & 0.12 & $94.8-98.9$ & 2.25 & 1.21 & 0.12 \\
$\mathrm{AFB}_{2}$ & 0.9997 & 0.03 & 0.09 & $93.1-97.1$ & 1.65 & 1.37 & 0.14 \\
$\mathrm{AFG}_{1}$ & 0.9995 & 0.06 & 0.18 & $93.2-97.2$ & 1.12 & 0.84 & 0.09 \\
$\mathrm{AFG}_{2}$ & 0.9998 & 0.05 & 0.15 & $92.8-96.2$ & 0.98 & 1.04 & 0.12 \\
Total AFs & 0.9993 & 0.13 & 0.39 & $92.8-98.9$ & 1.88 & 1.42 & 0.18 \\
\hline
\end{tabular}

HPLC high-performance liquid chromatography, AFB1 aflatoxin B1, AFB2 aflatoxin B2, AFG1 aflatoxin G1, AFG2 aflatoxin G2, LOD limit of detection. LOQ limit of quantification, $R M E$ relative mean error, $R S D$ relative standard deviation

Table 2 Summary of FAPAS ${ }^{\circledR}$ Proficiency Testing Program during 2012-2018

\begin{tabular}{|c|c|c|c|c|c|}
\hline \multirow[t]{2}{*}{ S. no. } & \multirow[t]{2}{*}{ Test no. } & \multirow[t]{2}{*}{ Commodity } & \multirow[t]{2}{*}{ Z-score } & \multicolumn{2}{|c|}{ Total aflatoxins $(\mu \mathrm{g} / \mathrm{kg})$} \\
\hline & & & & $\begin{array}{l}\text { Assigned } \\
\text { value }\end{array}$ & Lab. value \\
\hline 1 & $04328 / 2018$ & Rice & 0.9 & 9.61 & 11.55 \\
\hline 2 & 04203/2017 & Rice & 1.2 & 9.95 & 12.69 \\
\hline 3 & 04250/2014 & Maize & 1.6 & 11.20 & 15.07 \\
\hline 4 & $04216 / 2013$ & Maize & 0.3 & 7.99 & 8.6 \\
\hline 5 & $04188 / 2012$ & Rice & -0.2 & 23.00 & 21.93 \\
\hline
\end{tabular}

FAPAS Food Analysis Performance Assessment Scheme

the validation parameters and used to review the excellence, reliability and reproducibility of the results.

\section{Linearity}

The linearity of the HPLC technique was assessed by the determination of coefficient of determination $\left(R^{2}\right)$. The working standard solutions of AFs were prepared in the range of $0.05-80 \mathrm{ng} / \mathrm{mL}$ in $\mathrm{H} 2 \mathrm{O}: \mathrm{MeOH}(50: 50 ; \mathrm{v} / \mathrm{v})$ using stock solution of standard. The series were analyzed using HPLC and chromatographs were obtained. The calibration curves for each toxin were plotted between peak area and the related concentration. The values of $R^{2}$ were calculated by utilizing the regression equation [15]. The calibration curves were found linear in the tested range for each toxin with $R^{2}$ between $0.9994-0.9998$ (Table 1).

\section{Limit of detection (LOD) and quantification (LOQ)}

The values of LOD and LOQ were utilized for the determination of sensitivity of the HPLC method. Briefly, the LOD and LOQ were obtained using calibration curves. The values of LOD/LOQ for AFB1 (0.04/0.12), AFB2 (0.03/0.09), AFG1 (0.06/0.18), AFG2 (0.05/0.15) and total AFs were found $0.13 / 0.39 \mu \mathrm{g} / \mathrm{kg}$ as given in Table 1 . The attained values effectively satisfied the tolerated level as imposed by the EU and USA.

\section{Accuracy and precision}

The quality control (QC) (FAPAS QC material \# T07305QC; assigned value $=8.12 \mu \mathrm{g} / \mathrm{kg}$ ) was used to evaluate the accuracy and precision of the HPLC method. The QC sample $(n=20)$ was analyzed using the abovementioned protocol. Relative standard deviation (RSD) and relative mean error (RME) were calculated for the precision and accuracy, respectively. The values of RSD and RME were found in the range of $0.84-1.42 \%$, and $0.98-2.25 \%$, respectively, representing good performance of method (Table 1).

\section{Recovery}

The efficiency of the separation and chromatography technique was assessed by the fortification of samples. Accurately weight $25 \mathrm{~g}$ blank sample (confirmed by ELISA) was fortified with $0.5,5$ and $10 \mu \mathrm{g} / \mathrm{kg}$ of AFs standards at least $1 \mathrm{~h}$ prior to analysis. The fortified samples were analyzed and the AFs levels were quantified using HPLC technique. Finally, the percent recoveries of each toxin were calculated by the comparison of known and measured concentrations. Table 1 presents the average recoveries for each toxin. The mean recoveries were found in the range of 92.8 to $98.9 \%$ and fulfill the recommendations for recoveries limits as suggested by the Official Analytical Chemists, Codex Standard and the EU standards [16-18].

\section{Measurement uncertainty (Uc)}

The measurement uncertainty $(\mu \mathrm{c})$ for each AFs was calculated as stated by the quantifying uncertainty in analytical measurement (URACHEM). Briefly, homogenized QC samples $(n=20)$ were examined 5 intervals per day for 4 consecutive days. All recognized standard uncertainty constituents were assessed and type $\mathrm{A}(\mu \mathrm{A})$ and type $B(\mu B)$ uncertainties were determined. Finally, combined $\mu \mathrm{c}$ was assessed by merging $\mu \mathrm{A}$ and $\mu \mathrm{B}$. 


\section{Participation in proficiency testing program}

Unfortunately, proficiency testing program particularly for betel nuts was unavailable. Hence, Good Laboratory Practice (GLP) was verified in the testing program via test nos. 04328/2018, 04203/2017, 04250/2014, $04216 / 2013$ and $04188 / 2012$ in various foods such as rice and maize. Table 2 shows the obtained results and were found within the acceptable limit ( $\pm 2 Z$ score). In addition, food and feed safety laboratory has an ISO-17025 accreditation status with Pakistan National Accreditation Council (PNAC).

\section{Statistical data analysis}

Statistical data analysis was carried out by the Student's $t$ test with $p<0.05$ as the nominal level of significance unless specified otherwise. All experimental data were reported as the mean \pm standard deviation (SD).

\section{Results}

In this study, a total of 143 samples of betel nuts $($ India $=80$, Indonesia $=39$ and Sri Lanka $=24$ ) were obtained and tested for the AFs contamination. Significant data regarding AFs content in betel nuts are presented in Table 3. The whole betel kernels seem to be fresh and free from AFs contamination (Fig. 2a). However, when the kernel is crushed, the contamination is exposed and showing infection with fungi at the central portions of the kernels. The contaminated pods showed dark black or green patch appearance inside the nut as presented in Fig. 2b, c.

The range of AFs was found to be 1.18-378.94 $\mu \mathrm{g} / \mathrm{kg}$ with an average value of $84.38 \mu \mathrm{g} / \mathrm{kg}$. In $4(2.8 \%)$ samples, AFs level was found between 4 and $20 \mu \mathrm{g} / \mathrm{kg}$. In 46 (32.2\%) of tested samples, AFs level retained between 21 and $50 \mu \mathrm{g} / \mathrm{kg}$. Moreover, in a major group of $82(57.3 \%)$ samples, the AFs levels exceeded the $50 \mu \mathrm{g} / \mathrm{kg}$.

Only few studies have been conducted to evaluate the incidence of AFs in the betel nut samples and infestation was found in a number of samples (Table 4).

Table 3 Incidence of aflatoxins (AFB1, AFB2, AFG1 and AFG2) in betel nuts obtained from India, Indonesia and Sri Lanka

\begin{tabular}{|c|c|c|c|c|c|c|c|c|c|}
\hline \multirow[t]{2}{*}{ Country } & \multirow[t]{2}{*}{ Tested samples } & \multirow{2}{*}{$\begin{array}{l}\text { Positive } \\
\text { samples } n(\%)\end{array}$} & \multicolumn{5}{|c|}{ Number of samples in AFs concentration range, $\mu \mathrm{g} / \mathrm{kg}$} & \multirow[t]{2}{*}{ Average $(\mu \mathrm{g} / \mathrm{kg})$} & \multirow[t]{2}{*}{ Range $(\mu \mathrm{g} / \mathrm{kg})$} \\
\hline & & & $\mathrm{NF}$ & $<4$ & 4 to 20 & 21 to 50 & $>50$ & & \\
\hline India & 80 & $77(96.3)$ & $3(3.8)$ & $6(7.5)$ & $2(2.5)$ & $26(32.5)$ & $43(53.8)$ & $76.11 \pm 1.12$ & $1.18-331.57$ \\
\hline Indonesia & 39 & $39(100)$ & 0 & $2(5.1)$ & 0 & $9(23.1)$ & $28(71.8)$ & $123.76 \pm 1.25$ & $1.88-378.94$ \\
\hline Sri Lanka & 24 & $24(100)$ & 0 & 0 & $2(8.3)$ & $11(45.8)$ & $11(45.8)$ & $47.95 \pm 0.98$ & $4.74-106.58$ \\
\hline Total & 143 & 140 (97.9) & $3(2.1)$ & $8(5.6)$ & $4(2.8)$ & $46(32.2)$ & $82(57.3)$ & $84.38 \pm 1.09$ & $1.18-378.94$ \\
\hline
\end{tabular}

All measurements were made in triplicate and reported as mean $\pm \mathrm{SD}$

$N F$ not found within the detectable limit ( $\geq 1 \mu \mathrm{g} / \mathrm{kg}$ )

The aflatoxins contamination in various countries was significantly different from each other at $p<0.05$ according to analysis using ANOVA followed by Tukey post hoc analysis $(F$-value $=68.5428$; Degree of freedom $=462 ; p$-value $=0.004)$

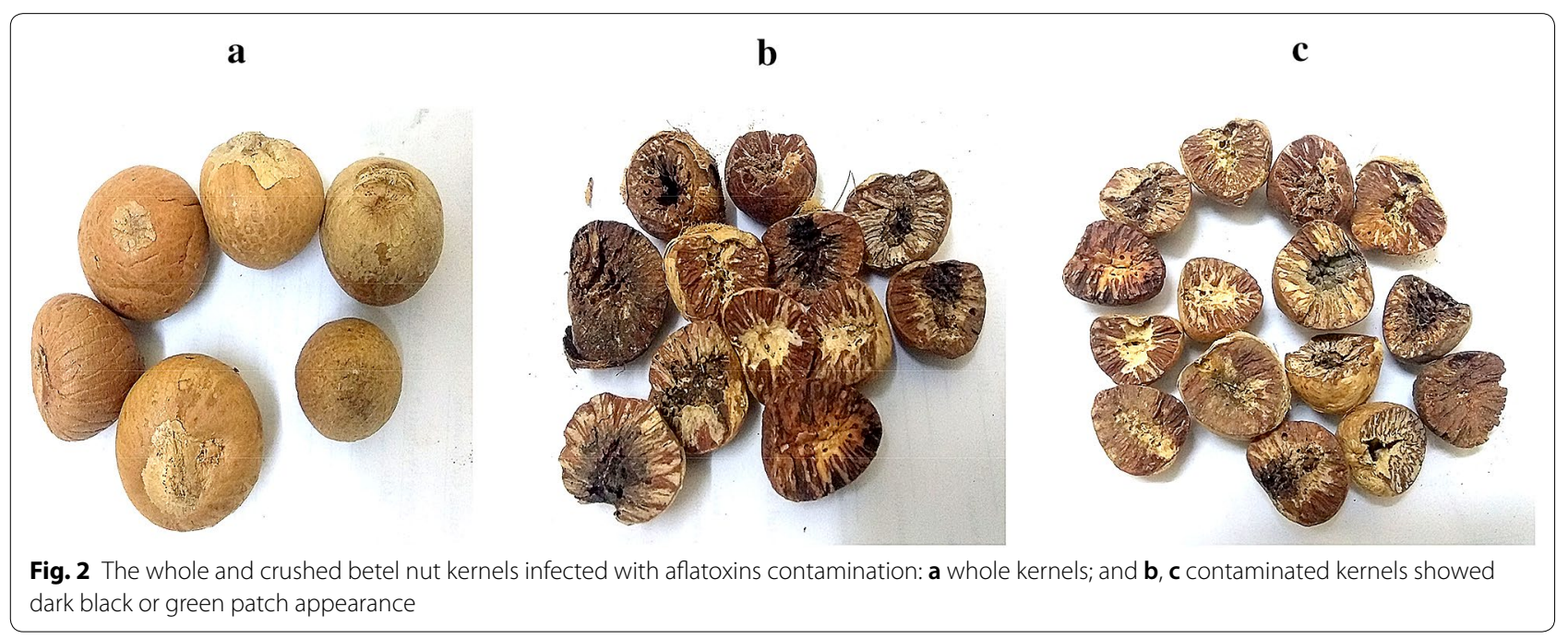


Table 4 The levels of aflatoxin B1 and total in betel nuts samples in different countries

\begin{tabular}{|c|c|c|c|c|c|c|c|c|}
\hline Country & Toxins & Sample no. & $\begin{array}{l}\text { Positive } \\
\text { samples (\%) }\end{array}$ & $\begin{array}{l}\text { Maximum } \\
(\mu \mathrm{g} / \mathrm{kg})\end{array}$ & Range $(\mu \mathrm{g} / \mathbf{k g})$ & Average & Year of survey & Authors \\
\hline India & $\mathrm{AFB}_{1}$ & 278 & 100 & 262.0 & $11.7-262.0$ & 92.5 & 2010-2011 & Asghar et al. [23] \\
\hline Indonesian & & & 80.4 & 39.2 & $3.3-39.2$ & 11.6 & & \\
\hline Sri-Lankan & & & 73.5 & 103.4 & $6.5-103.4$ & 35.0 & & \\
\hline Thailand & & & 30.2 & 77.0 & $3.3-77.0$ & 6.6 & & \\
\hline Bangladesh & AFs & NR & $N R$ & NR & NR & 30.6 & 2009 & Roy et al. [24] \\
\hline South Africa & AFs & NR & NR & 26.2 & $3.5-26.2$ & $N R$ & 1996 & Van der Bijl et al. [25] \\
\hline India & $\mathrm{AFB}_{1}$ & 32 & 40 & 208 & $18-208$ & 94 & 1991 & Raisuddin and Misra [26] \\
\hline
\end{tabular}

NR not reported by author

Refer figures and figures caption

\section{Aflatoxins level in Indian betel nuts samples}

The present result showed that 77 (96.3\%) out of 80 Indian betel nut samples were contaminated with AFs contamination. The range of AFs was found between $1.18-331.57 \mu \mathrm{g} / \mathrm{kg}$ with a mean value of $76.11 \mu \mathrm{g} / \mathrm{kg}$. Only $9(11.3 \%)$ and $11(13.8 \%)$ samples of betel nuts were below the MTL for AFs as suggested by EU and USA in food commodities, respectively. Furthermore, in 26 (32.5\%) samples, AFs level was found between 21 and $50 \mu \mathrm{g} / \mathrm{kg}$. Moreover, in a group of $43(53.8 \%)$ samples, the AFs level exceeded the $50 \mu \mathrm{g} / \mathrm{kg}$.

\section{Aflatoxins level in the Indonesian betel nuts samples}

The contamination range was found to be $1.88-378.94 \mu \mathrm{g} /$ $\mathrm{kg}$ with an average level of $123.76 \mu \mathrm{g} / \mathrm{kg}$. About 37 (94.9\%) samples exceeded the MTL of AFs as assigned by the EU and USA. Furthermore, in 9 (23.1\%) samples, AFs level was found between 21 and $50 \mu \mathrm{g} / \mathrm{kg}$. However, in 28 (71.8\%) samples the AFs levels exceeded $50 \mu \mathrm{g} / \mathrm{kg}$.

\section{Aflatoxins level in Sri Lankan betel nuts samples}

The contamination range was found to be $4.74-106.58 \mu \mathrm{g} / \mathrm{kg}$ with a mean level of $47.95 \mu \mathrm{g} / \mathrm{kg}$. About 22 (91.7\%) samples out of 24 samples exhibited AFs level greater than MTL for AFs as established by EU and USA. In $11(45.8 \%)$ samples, AFs level was found between 21 and $50 \mu \mathrm{g} / \mathrm{kg}$. Moreover, the same number of samples exceeded the AFs levels of $50 \mu \mathrm{g} / \mathrm{kg}$. The average and maximum concentration of AFs in betel nuts samples in South Asian countries are shown in Fig. 3. The present results indicated that the maximum concentration of AFs equivalent to $378.94 \mu \mathrm{g} / \mathrm{kg}$ was detected in betel nuts trade from Indonesia. In contrast, the lowest concentration of AFs corresponding to $106.58 \mu \mathrm{g} / \mathrm{kg}$ was noticed in betel nuts shipments obtained from Sri Lanka. Furthermore, the significant variances in AFs contamination in various countries was noted from each other at $p<0.05$ according to analysis using ANOVA followed by Tukey post hoc analysis $(F$-value $=68.5428$; degree of freedom $=462 ; p$-value $=0.004$ ).

\section{Discussion}

Aflatoxins (AFs) are food contaminant and potential risk to the human health due to their carcinogenic effect. They are able to grow during harvesting, handling carrying and storage in both tropical and sub-tropical environment.

The whole results indicated that about 140 (97.9\%) samples of betel nuts were contaminated with AFs contamination. AFs contamination in 132 (92.3\%) betel nut samples was found greater than maximum tolerated limit (MTL) of $4 \mu \mathrm{g} / \mathrm{kg}$ as recommended by the European Union in food and nuts [18]. Furthermore, 128 (89.5\%) samples exceeded the MTL of $20 \mu \mathrm{g} / \mathrm{kg}$ as assigned by the Food and Drug Administration (FDA) in all food commodities [19].

The results indicated that the all tested samples obtained from Indonesia were infected with AFs at highlevel contamination. Moreover, it was observed that all tested samples of Sri Lankan origin were infected with AFs contamination.

More than 95\% consignments of betel nuts were declared unfit for human consumption with respect to high-level AFs contamination. Accordingly, the consignments were rejected and required deportation or destruction of betel nuts as per rules 13 of Pakistan Plant Quarantine Rules 1967 and guidelines of international plant protection convention.

It was noticed that the contamination level of AFs in betel nuts differs with deference to their origin of country. The reason is that each country accumulates variable humidity and temperature, soil type, microbial flora and various agricultural practices. It has been reported that the hot and moist conditions are probably more encouraging for the development of aflatoxigenic fungi and AFs 


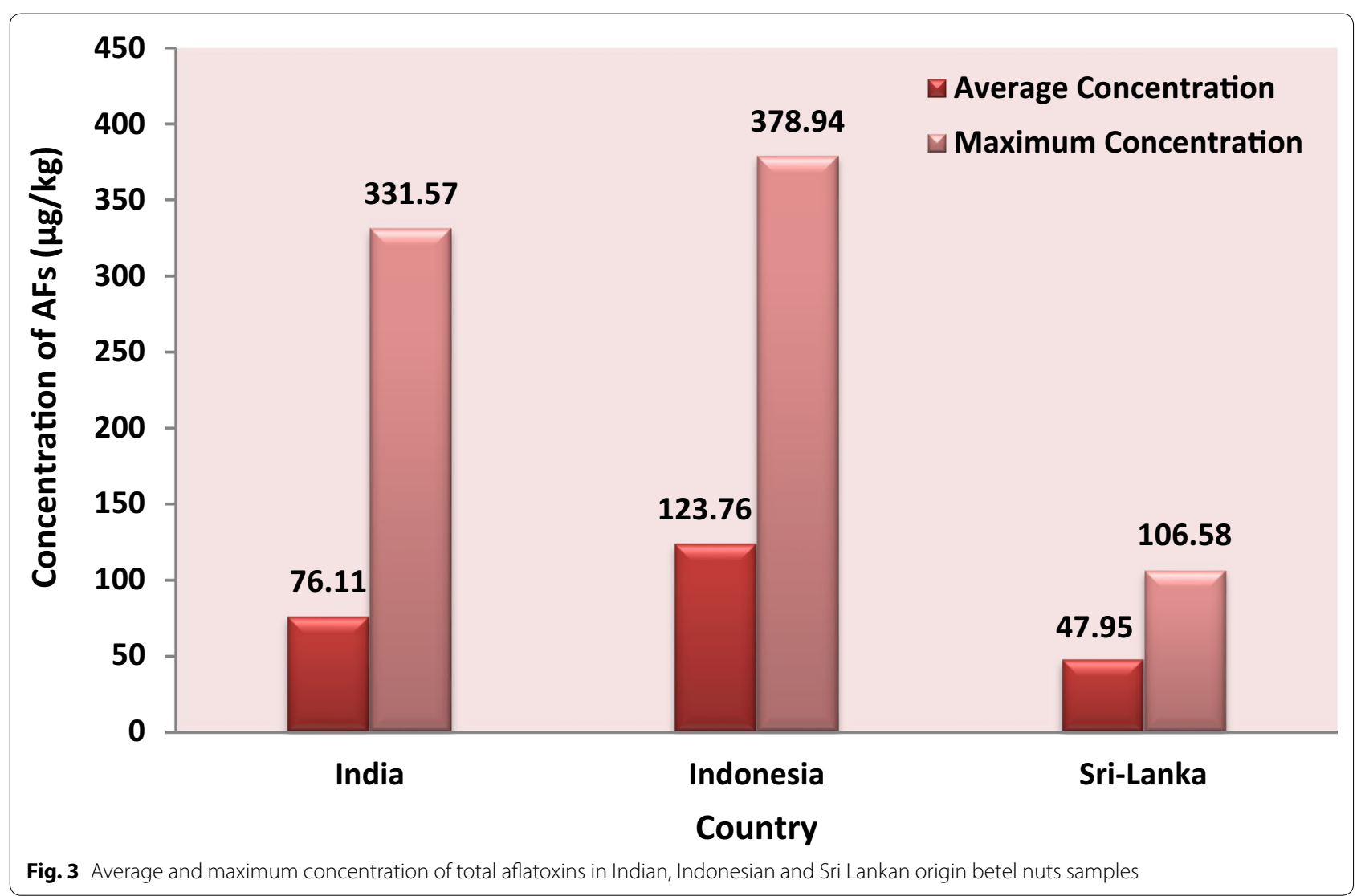

production in agricultural foodstuffs [20]. Also, the preand post-harvest weather environments directly influence on the incidence and level of AFs contamination in agricultural produces.

The climate of the Southeast Asia countries is mostly tropical-hot and humid with plentiful rainfall during in whole year. The weather of Southeast Asia countries can be split into three basic kinds i) tropical, ii) dry and iii) temperate [21]. The northeast areas have tropical to subtropical (temperate) weather. On moving towards the west, the moisture and altitude changes, producing a steppe and a desert climate that is similar the Middle East. The average temperature is around 25, 27 and 26oC and average total yearly precipitation was 1784, 2581 and $1702 \mathrm{~mm}$ in India, Indonesia and Sri Lanka, respectively [22]. It is assumed that these hot and humid climatic environments encourage the aflatoxigenic molds and resulting in AFs production [20].

It was identified that the inappropriate storage and transportation conditions are the most vital factors and leading to the formation of aflatoxigenic molds and AFs contamination. Normally, containers are increasingly being used to carry the consignment and arriving in around 35-40 days from South Asian countries to Pakistan. During shipping, the storage condition is not at a optimized level. The environment of sea also facilitates the fungal growth and ultimately AFs production. In many cases, container liners are used to protect the foodstuffs being carried. The polyethylene and polypropylene are best the liners and commonly used to shield bulk dry products.

Only few studies have been conducted to evaluate the incidence of AFs in the betel nut samples and infestation was found in a number of samples. For instance, the frequency and average contamination level of AFB1 in betel nuts was greater in our previous study. A total of 278 betel nuts samples being imported to Pakistan from South Asian countries were analyzed for the occurrence of AFB1. All samples obtained from India were infected with AFB1, ranging between 11.7 and $262.0 \mu \mathrm{g} / \mathrm{kg}$ with an average level of $92.5 \mu \mathrm{g} /$ $\mathrm{kg}$; whereas, $80.4 \%$ and $73.5 \%$ samples of betel nuts received from Indonesian and Sri Lanka were contaminated with AFB1. The contaminations ranged were 3.339.2 and $6.5-103.4 \mu \mathrm{g} / \mathrm{kg}$ and mean level were 11.6 and $35.0 \mu \mathrm{g} / \mathrm{kg}$, respectively; whereas, only $30.2 \%$ samples obtained from Thailand were contaminated with AFB1 ranged between 3.3 and $77.0 \mu \mathrm{g} / \mathrm{kg}$ and mean level was $6.6 \mu \mathrm{g} / \mathrm{kg}$ [23]. A study from Bangladesh reported that the mean level of AFs contamination in betel nuts was 
found to be $30.6 \mu \mathrm{g} / \mathrm{kg}$ [24]. Furthermore, Van der Bijl et al. also reported from South Africa that the total AFs content was in the range of $3.5-26.2 \mu \mathrm{g} / \mathrm{kg}$ in raw and sliced betel nut samples [25]. About $40 \%$ samples exceeded the MTL of AFs level as usually accepted in foodstuff of $5 \mu \mathrm{g} / \mathrm{kg}$. Raw betel nut samples were found more contaminated with Aspergillus flavus as compare to sliced betel nuts. The study from India reported that 12 (40\%) samples of betel nuts out 32 analyzed samples were contaminated with AFs. AFB1 was detected in all the positive samples. The contamination range was found to be $18-208 \mu \mathrm{g} / \mathrm{kg}$ with a mean level of $94 \mu \mathrm{g} /$ $\mathrm{kg}$. In $9(28 \%)$ samples, the concentration of AFB1 was greater than $50 \mu \mathrm{g} / \mathrm{kg}$ [26].

The above declared studies specified that the contamination of AFs in betel nuts is frequently occurring in all over the world. The metabolism of AFs occurred in liver by cytochrome P-450 and produces aflatoxin-albumin adducts, which may be responsible for mutagenesis in liver. Hence, the liver damage in betel nut habitual could be caused by the combined effect of both AFs and alkaloids of betel nut [3]. They target the hepatocytes resulting in increased serum transaminases, alkaline phosphatase and total bilirubin, which are markers for liver damage. Furthermore, Kolhe and Patil reported that AFs contamination of betel nut and tobacco might be responsible for induced cytotoxicity and cancer [27]. In addition, the both synergistic and additive effects of AFs and alkaloid of betel nuts are accountable for immunosuppression and result in hepatic damage [2]. Therefore, it is earnestly required to conduct training programs on regular basis to provide knowledge about the toxicity potential of AFs. Additionally, good harvesting practices, handling, packing, storing and carriage conditions must be acquired along with execution on Hazard Analysis and Critical Control Points (HACCP) based food safety program. In addition, it is very unfortunate that harvesting, storage and sampling practices are generally not standardized within developing countries. Care must be taken during sampling, handling, testing and elucidation of results of commodities on regular basis.

The sampling of the commodities must be done in way that it represents the total lot under assessment. Also, the validated testing procedure with low standard deviation among the replicates must be adopted. Furthermore, the MTL for betel nuts has not been established by the Food Authority in various countries. The regulations related to the mycotoxins contamination in betel nuts have to be recognized by the Food Safety Acts of those countries. The food items imported from another country that are planned for human utilization must encounter the general food security requirements.

\section{Conclusion}

Based on the attained results, it was decided that the status of the AFs level in betel nuts exported from South Asian (India, Indonesia and Sri Lanka) countries to Pakistan is rather high and consumption of betel nut could be a severe problem for human health. The detection of AFs in betel nuts indicates the need of further investigation and performing analysis on routine basis as per standards of food quality control before import/ export. The contamination of AFs in betel nuts can be reduced by adopting better harvesting techniques, proper storage and transport. It is much important for food regularity bodies of Pakistan to assess the levels of AFs in betel nut on regular basis to avoid public health hazards. It is also recommended that high-level contaminated products with AFs should be withdrawn from the market by the public health authorities.

\section{Abbreviations \\ AFs: Aflatoxins; ACN: Acetonitrile; AOAC: Association of Official Agricultural Chemists; FDA: Food and Drug Administration; GLP: Good Laboratory Practice; HACCP: Hazard Analysis and Critical Control Points; HPLC: High-performance liquid chromatography; IAC: Immunoaffinity column; IARC: International Agency for Research on Cancer; LOQ: Limit of quantification; LOD: Limit of detection; MTL: Maximum tolerated limit; PNAC: Pakistan National Accredi- tation Council; QC: Quality control; RSD: Relative standard deviation; RME: Relative mean error.}

\section{Acknowledgements}

The present study work was supported by Food and Feed Safety Laboratory, PCSIR Laboratories Complex, Karachi.

\section{Authors' contributions}

M Asif conducted the whole study under AA supervision. M Arif revised the paper and help during the practical work, M Asif and M Arif were responsible for drafting and writing the final version of the manuscript. All authors performed data analysis. All authors read and approved the final manuscript.

Funding

The authors did not receive financial support from any institution.

Availability of data and materials

The data sets used and/or analyzed during the current study are available from the corresponding author on reasonable request.

\section{Ethics approval and consent to participate}

Not applicable.

\section{Consent for publication}

Not applicable.

\section{Competing interests}

The authors declare that they have no competing interests.

\author{
Author details \\ ${ }^{1}$ Food and Feed Safety Laboratory, Food and Marine Resources Research \\ Centre, PCSIR Laboratories Complex, Shahrah-e-Salimuzzaman Siddiqui, Off \\ University Road, Karachi 75280, Sindh, Pakistan. ${ }^{2}$ Department of Pharmaceu- \\ tics, Faculty of Pharmacy, Jinnah Sindh Medical University, Rafiqui H.J Shaheed \\ Road, Karachi 75510, Sindh, Pakistan.
}

Received: 22 April 2020 Accepted: 17 July 2020

Published online: 14 October 2020 


\section{References}

1. Boucher BJ, Mannan N. Metabolic effects of the consumption of Areca catechu. Addict Biol. 2002:7(1):103-10.

2. Choube S, Bhowate R. Betel-nut-induced oral lichenoid lesion in oral submucous fibrosis and its relation with liver enzymes and hepatitis $C$ virus-ribonucleic acid. J Ind Acad Oral Med Radiol. 2018;30(3):265-8.

3. IARC. International Agency for Research on Cancer. IARC monographs on the Betel-quid and areca-nut chewing and some areca-nut-derived nitrosamines, vol. 85. Lyon: IARC Press; 2004.

4. Trivedy C, Craig G, Warnakulasuriya $S$. The oral health consequences of chewing areca nut. Addict Biol. 2002;7(1):115-25.

5. IRAC. International Agency for Research on Cancer. IARC monographs on the evaluation of carcinogenic risks to humans. Ingested nitrate and nitrite, and cyanobacterial peptide toxins, vol. 94. Lyon: IARC Press; 2010

6. Dwevedi A, Kumar P, Kumar P, Kumar Y, Sharma YK, Kayastha AM. Soil sensors: detailed insight into research updates, significance, and future prospects. New Pest Soil Sens. 2017;561-94. Elsevier.

7. Varga J, Frisvad JC, Samson R. Two new aflatoxin producing species, and an overview of Aspergillus section Flavi. Stud Mycol. 2011;69:57-80.

8. Nigam SN, Waliyar F, Aruna R, Reddy SV, Kumar PL, Craufurd PQ, Diallo AT, Ntare BR, Upadhyaya HD. Breeding peanut for resistance to aflatoxin contamination at ICRISAT. Peanut Sci. 2009;36(1):42-9.

9. Lereau M, Gouas D, Villar S, Besaratinia A, Hautefeuille A, Berthillon P, Martel-Planche G, da Costa AN, Ortiz-Cuaran S, Hantz O, Pfeifer GP. Interactions between hepatitis B virus and aflatoxin B1: effects on p53 induction in HepaRG cells. J Gener Virol. 2012;93(3):640-50.

10. Alim M, labal SZ, Mehmood Z, Asif MR, Zikar H, Chanda H, Malik N. Survey of mycotoxins in retail market cereals, derived products and evaluation of their dietary intake. Food Cont. 2018;84:471-7.

11. FSSAI. Food Safety and Standards Authority of India. Gazette notification of Food Safety and Standards (Contaminants, Toxins and Residues) Second Amendment Regulation, 2017 regarding fixation of the limits of aflatoxin in areca nut. 2018.

12. Asghar MA, Ahmed A, Zahir E, Asghar MA, lqbal J, Walker G. Incidence of aflatoxins contamination in dry fruits and edible nuts collected from Pakistan. Food Cont. 2017;78:169-75.

13. European Commission. Commission Regulation (EC) no. 2002/657/EC of 12 August 2002, implementing Council Directive 96/23/EC concerning the performance of analytical methods and the interpretation of results. Off J Euro Union. 2002;2002(221):8-36.

14. European Commission. Commission Regulation (EC) no. 2002/657/EC of 12 August 2002, implementing Council Directive 96/23/EC concerning the performance of analytical methods and the interpretation of results. J Euro Union. 2002;2002(221):8-36.

15. Lane DM. Introduction to linear regression. 2012. http://onlinestatbook. com/2/regression/intro.html./.

16. AOAC International. AOAC guidelines for single laboratory validation of chemical methods for dietary supplements and botanicals. Gaithersburg: AOAC International. 2002. http://www.aoac.org/Official_Methods/ slv_guidelines.pdf/.

17. Codex. Codex standard for contaminants and toxins in food and feed. Codex standard. 1995. http://www.codexalimentarius.net/.../download/ standards/17/CXS_193e.pdf./.

18. European Commission. Commission Regulation (EC) no. 165/2010 of 26 February 2010. Amending Regulation (EC) No 1881/2006 setting maximum levels for certain contaminants in foodstuffs as regards aflatoxins. Off J Euro Union. 2010;L50(2010):8-12.

19. U.S. Food and Drug Administration. Guidance for industry: action levels for poisonous or deleterious substances inhuman food and animal feed. 2000. http://www.fda.gov/.

20. Reddy K, Reddy C, Abbas H, Abel C, Muralidharan K. Mycotoxigenic fungi, mycotoxins, and management of rice grains. Toxin Rev. 2008;27(3-4):287-317.

21. Sterrett C. Review of climate change adaptation practices in South Asia. Oxfam policy and practice. Clim Change Resil. 2011;7(4):65-164.

22. Climatemps. 2018. http://www.climatemps.com.

23. Asghar MA, lqbal J, Ahmed A, Khan MA, Shamsuddin ZA. Aflatoxin B1 in betel nuts (Areca catechu L.) imported to Pakistan from different regions of South Asia. Food Addit Cont Part B. 2014;7(3):176-81.

24. Roy M, Harris J, Afreen S, Deak E, Gade L, Balajee SA, Park B, Chiller T, Luby S. Aflatoxin contamination in food commodities in Bangladesh. Food Addit Cont Part B. 2013;6(1):17-23.

25. Van der Bijl P, Stockenström S, Visme HF, Van Wyk CW. Incidence of fungi and aflatoxins in imported areca nut samples. South Afr J Sci. 1996;92:154-6.

26. Raisuddin S, Misra J. Aflatoxin in betel nut and its control by use of food preservatives. Food Addit Cont. 1991;8(6):707-12.

27. Kolhe A, Patil N. Cytotoxicity of aqueous extract of arecanut and tobacco on human erythrocytes (red blood corpuscles). Int Res J. 2009;2:539-40.

\section{Publisher's Note}

Springer Nature remains neutral with regard to jurisdictional claims in published maps and institutional affiliations.
Ready to submit your research? Choose BMC and benefit from:

- fast, convenient online submission

- thorough peer review by experienced researchers in your field

- rapid publication on acceptance

- support for research data, including large and complex data types

- gold Open Access which fosters wider collaboration and increased citations

- maximum visibility for your research: over $100 \mathrm{M}$ website views per year

At BMC, research is always in progress.

Learn more biomedcentral.com/submissions 